\title{
Komunikasi Massa Dalam Pariwisata Religi Hindu
}

\author{
Ni Nyoman Ayu Wilantari \\ Institut Agama Hindu Tampung Penyang (IAHN-TP) Palangka Raya \\ putukania65@gmail.com
}

\begin{abstract}
Riwayat Jurnal
Artikel diterima: 25 Juli 2018

Artikel direvisi: 14 September 2018

Artikel disetujui: 13 Oktober 2018
\end{abstract}

\section{Kata Kunci:}

Komunikasi massa Pariwisata religi Hindu Tirthayatra

\section{Abstrak}

Komunikasi adalah sebuah proses penyampaian informasi dari pemberi berita atau komunikator yang sarat akan lambanglambang agar si penerima pesan atau komunikan bisa memahami maksud dan tujuan dari berita yang disampaikan tersebut. Berbagai era sudah di lalui manusia untuk melakukan komunikasi di dunia ini. Salah satu jenis komunikasi adalah komunikasi massa, artinya komunikasi yang menggunakan media massa dan bisa juga diartikan komunikasi yang dilakukan dengan orang banyak. Komunikasi massa dalam Pariwisata Indonesia di era globalisasi berperan penting karena dengan adanya media massa maka pengembangan sektor pariwisata di Indonesia yang terdapat banyak hotel, restoran maupun sarana transportasi sebagai penunjang berjalannya roda perekonomian di sektor pariwisata dan bisa diakses dengan mudah. Dalam Wisata Religi, khususnya wisata religi Hindu maka produk-produk yang dapat ditawarkan antara lain produk perjalanan menuju Pura Besakih, Pura Uluwatu, Pura Batur di Bali bagi umat Hindu yang berada di luar Pulau Bali. Produk wisata religi keluar negri yang dapat di tawarkan berupa perjalanan ke India, mengunjungi Sungai Gangga dan lain sebagainya.

\section{Keyword:}

Mass communication Hindu religious tourism tirthayatra

\begin{abstract}
Communication is a process of delivering information from news givers or communicators that are full of symbols so that the recipient of the message or communicant can understand the intent and purpose of the news delivered. Various eras have been passed by humans to communicate in this world. One type of communication is mass communication, meaning that connection uses mass media and can also mean discussion that done with many people. Mass communication in Indonesian Tourism in the era of globalisation has an essential role because with the mass media, the development of the tourism sector in Indonesia, which has many hotels, restaurants and transportation facilities to
\end{abstract}




\begin{tabular}{|l|l|}
\hline $\begin{array}{l}\text { Support the running of the economy in the tourism sector and can } \\
\text { be easily accessed. In Religious Tourism, especially Hindu } \\
\text { religious tourism, the products that can be offered include travel } \\
\text { products to Besakih Temple, Uluwatu Temple, Batur Temple in } \\
\text { Bali for Hindus outside of Bali. Religious tourism products out of } \\
\text { the country that can be offered in the form of trips to India, } \\
\text { visiting the Ganges river and so forth. }\end{array}$ \\
\hline
\end{tabular}

\section{Pendahuluan}

Alam indah nan hijau bagaikan zamrud khatuslistiwa menjadi wajah Indonesia dimata dunia. Tak heran jika banyak negara-negara asing yang ingin memiliki Indonesia karena selain cantik Indonesia juga memiliki kekayaan yang berlimpah dari hasil rempah-rempah hingga gas bumi sampai hasil tambang. Kecantikan Indonesia juga didukung oleh kemajemukkan suku, bahasa dan Agama. Sebagai manusia dan penduduk Indonesia khususnya, seseorang melakukan interaksi dengan orang-orang sekitarnya dengan bersosialisasi dan berkomunikasi. Manusia sejak mereka dilahirkan sudah berkomunikasi dengan orang-oarang disekitarnya, dengan mengeluarkan kata-kata maupun hanya sekedar menjadi pendengar. Jika mereka mengeluarkan kata- kata atau berita yang disampaikannya maka mereka disebut sebagai komunikator namun apabila mereka hanya menjadi pendengar atau penerima pesan maka mereka disebut sebagai komunikan.

Komunikas dari tahun ke tahun mengalami perkembangan yang sangat pesat dan semakin maju, penemuan-penemuan baru di bidang sarana-sarana komunikasi seperti dipergunakannya surat untuk berkirim kabar melalui POS dilanjutkan penemuan telepon untuk bisa berkomunikasi jarak jauh serta media-media komunikasi lain yang digunakan untuk memberikan informasi. Diawali dengan penemuan mesin cetak yang dipergunakan untuk mencetak koran serta majalah yang disebut sebagai media cetak, penemuan radio dan televisi untuk memberikan serta menyajikan hiburan melalui audio visual. Dilanjutkan lagi dengan penemuan internet sebagai media online dan media multifungsi karena bisa didengar sekaligus dilihat dan juga bisa dibaca. Kehadiran teknologi multimedia ini menandakan lahirnya generasi baru yaitu generasi milenial semua orang dapat terhubung satu sama lain dengan mudahnya. Dunia telah menjadi "kampong dunia" dengan mudahnya diketahui berita disekitar dan berita di belahan dunia lain.

Internet melahirkan berbagai media online atau media sosial seperti youtube, blog, facebook, instagram, twitter, pinterest, tumblr, flickr, linkldn, goegle plus, serta melahirkan media massa seperti situs berita online, web berita online, surat kabar online serta majalah- 
majalah online dan lain sebagainya, sehingga disebut sedang melakukan komunikasi massa. Dari media-media sosial inilah dapat diketahui dengan cepat bebagai peristiwa bagaimana keadaan cuaca, bencana apa yang terjadi, keindahan alam di wilayah lain, dunia dapat terlihat dalam genggaman smart phone sebagai alat komunikasi yang canggih. Begitu mudahnya akses untuk melihat belahan dunia lain di media sosial menimbulkan hasrat untuk melakukan kegiatan pariwisata. Orang yang melakukan kegiatan pariwisata ini disebut dengan istilah wisatawan. Berbagai macam dan jenis kegiatan pariwisata dilakukan seperti pariwisata budaya, pariwisata kuliner, pariwisata bahari, pariwisata sejarah, pariwisata cagar alam (konservasi), pariwisata religi dan lain sebagainya. Sebagai Umat Hindu pastilah terbersit keinginan untuk melakukan perjalanan ketempat-tempat suci seperti Pura, Mandir, dan sugai-sungai suci kegiatan perjalanan ini termasuk dalam pariwisata religi.

\section{Pembahasan}

\section{Komunikasi Massa dalam Pariwisata}

Komunikasi bukan sekadar untuk menunjang kehidupan tetapi sebagai dasar kehidupan (basic of life) seperti halnya oksigen dan makanan, komunikasi juga diperlukan untuk menjamin kehidupan seseorang, bahwa seseorang bisa mati berdiri jika tidak ada yang mau berkomunikasi dengannya Ibnu (dalam Ruben dan Stewart, 2017: vii). Manusia sejak mereka dilahirkan sudah berkomunikasi dengan orang-orang disekitarnya, dengan mengeluarkan kata-kata maupun hanya sekedar menjadi pendengar. Jika mereka mengeluarkan kata-kata atau berita yang disampaikannya maka mereka disebut sebagai komunikator namun apabila mereka hanya menjadi pendengar atau penerima pesan maka mereka disebut sebagai komunikan. Menurut Feisher (dalam Arifin, 20: 2010), persoalan sosial dari waktu ke waktu yang selalu melibatkan komunikasi. Penyelesaian masalah sosial yang ada di masyarakat, terkait baik buruknya komunikasi lisan maupun komunikasi tertulis seseorang dalam menyelesaikan masalahnya sehingga akan membuat pihak-pihak yang bertikai bisa mencapai kesepakatan dan perdamaian.

William Albig (dalam Arifin, 25: 2010) menyatakan bahwa komunikasi adalah proses pengoperan lambang-lambang yang berarti antara individu-individu. Rogers (dalam Noegroho, 2010: 9), menyebutkan empat era evolusi komunikasi manusia, yakni era writing, era printing, era telecommunication, dan era komunikasi interaktif. Jadi komunikasi adalah sebuah proses penyampaian informasi dari pemberi berita atau komunikator yang sarat akan lambang- lambang agar si penerima pesan atau komunikan bisa memahami maksud dan tujuan dari berita yang disampaikan tersebut. Berbagai era sudah di lalui manusia untuk 
melakukan komunikasi di dunia ini. Sedangkan Carl I. Hovland (dalam Effendy, 2011: 10), menyatakan ilmu komunikasi adalah upaya yang sistemastis untuk merumuskan secara tegas asas-asas penyampaian informasi serta pembentukan pendapat dan sikap. Pendapat Hovland ini di dukung dengan pendapat Rohim (2009: 27) yang menyatakan ilmu komunikasi merupakan salah satu ilmu pengetahuan yang bersifat multidisipliner. Hal ini terjadi karena ilmu komunikasi berkembang melalui beberapa pendekatan seperti pendekatan yang berasal dari ilmu sosiologi, psikologi, politik, linguistik, antropologi, dan lainnya.

Salah satu bagian dalam ilmu komunikasi adalah komunikasi massa. Istilah komunikasi massa diadopsi dari istilah bahasa Inggris, mass communication, sebagai kependekan dari mass media communication. Artinya, komunikasi yang menggunakan media massa (Ngalimun, 2017: 89). Ilmu komunikasi massa (mass communication science) berkembang di Amerika Serikat melalui jurnalistik. Jurnalistik sebagai suatu keterampilan dalam bentuk surat kabar sudah mulai dikenal di Amerika Serikat sejak tahun 1700 (Arifin, 2010: 6 ). Senada dengan hal tersebut Bleyer ( dalam Arifin, 2010: 8 ) memasukkan jurnalistik sebagai minor program ilmu sosial di Universitas Wisconsin tahun 1930an, setelah perang dunia II. Para ahli merasa bahwa jurnalistik tidak lagi mampu menampung berbagai pengkajian, sehingga perlu memberi nama yang lebih sesuai yaitu ilmu komunikasi massa, objek kajiannya tidak lagi sebatas surat kabar tetapi mencakup juga radio, film, dan televisi sehingga keempat media itu disebut media massa.

Media massa di negara yang memiliki sistem kemasyarakatan yang tidak terlalu individualistis, komunal, tidak terlalu sekuler, atau masyarakat yang lebih religious biasanya akan memiliki media massa yang berbeda dengan negara barat dengan sistem politik dan ekonomi yang lebih liberal (Morissan, 2013: 481). Massa mengandung pengertian orang banyak, mereka tidak harus berada di lokasi tertentu yang sama atau hampir bersamaan dapat memperoleh pesan-pesan komunikasi yang sama (Ngalimun, 2017: 90). Komunikasi massa ialah komunikasi yang isinya bersifat umum atau terbuka, sehingga mencakup komunikasi dengan menggunakan media massa (pers, radio, film, dan televisi ) maupun komunikasi dengan langsung atau sering disebut retorika dan pembicaraan di depan umum (Arifin, 30-31 : 2010 ).

Menurut Effendy (2011: 22-25) sebagai berikut.

Ciri-ciri komunikasi massa adalah komunikasi berlangsung satu arah (one-way communication) yang berarti tidak terdapat arus balik dari komunikan kepada komunikator. Wartawan sebagai komunikator tidak memgetahui tanggapan para pembaca, pendengar ataupun penonton terhadap pesan atau berita yang disajikannya 
tersebut. Ciri kedua dari komunikasi massa adalah komunikator pada komunikasi massa melembaga, artinya media massa sebagai saluran komunikasi massa merupakan lembaga, yakni suatu institusi atau organisasi. Komunikator pada komunikasi massa, misalnya wartawan surat kabar atau penyiar televisi, karena media yang dipergunakannya adalah suatu lembaga dalam menyebarluaskan pesan komunikasinya dan bertindak atas nama lembaga. Ciri ketiga dari komunikasi massa adalah pesan pada komunikasi massa bersifat umum, artinya pesan yang disebarkan melalui media massa bersifat umum karena ditujukan kepada umum dan mengenai kepentingan umum. Ciri keempat dari komunikasi massa yaitu media komunikasi massa menimbulkan keserempakan, artinya kemampuan media komunikasi massa untuk menimbulkan keserempakan pada pihak khalayak dalam menerima pesan-pesan yang disebarkan. Ciri kelima dari komunikasi massa yaitu komunikaan dari komunikasi massa bersifat heterogen, artinya anggota masyarakat yang terlibat dalam proses komunikasi massa sebagai sasaran yang dituju komunikator bersifat heterogen. Dalam keberadaannya secara terpencar-pencar, di mana satu sama lainnya tidak saling mengenal dan tidak memiliki kontak pribadi dan mereka juga berbeda jenis kelamin, usia, agama, ideology, pekerjaan, pendidikan, pengalaman, kebudayaan, keinginan, cita-cita, dan lain sebagainya.

Komunikasi massa adalah proses yang dipakai komunikator massa untuk mengirimkan pesan mereka kepada audien massa. Kemampuan untuk menjangkau ribuan, atau bahkan jutaan orang merupakan ciri dari komunikasi massa (Vivian, 2008:450- 451). Komunikasi massa yang merupakan komunikasi media massa pasti mempergunakan teknologi di dalam menjalankan peran komunikasi massanya di masyarakat. Ciri masyarakat informasi yaitu semakin mendominasinya sektor informasi dalam kehidupan masyarakat. Dalam era ini produksi, penyimpanan, pengolahan, penerapan dan penyampaian informasi sudah semakin tinggi baik kuantitatif maupun kualitatif (Noegroho, 2010: 25). Sejalan dengan hal itu Jussawala (dalam Noegroho, 2010: 8), menyatakan masyarakat modern saat ini sedang menempuh periode yang paling mengasyikan dalam sejarah kehidupannya, karena mengalami perubahan teknologi yang besar dan cepat, maka negara-negara diseluruh dunia akan mendapatkan pertumbuhan ekonomi mereka pada investasi yang dilakukan di bidang teknologi yang inovatif.

Makin pesatnya laju komunikasi massa berbasis teknologi di belahan dunia manapun akibat dari meningkatnya pertumbuhan ekonomi di negara-negara modern, menyebabkan negara-negara lain yang masih berkembang berusaha mengejar ketertinggalan mereka di dalam komunikasi massa berbasis teknologi ini. Rogers (dalam Noegroho,2010: 12), menyatakan teknologi komunikasi sudah merubah pradigma lama tentang komunikasi dengan cara- cara yang tradisional menjadi pola komunikasi bermedia yang interaktif. Karakteristik sistem komunikasi manusia sebagai akibat tekologi komunikasi yaitu Interactivity, komponen teknologi elektronik yang ada memungkinkan adanya komunikasi dengan medianya secara 
automatic atau mechanical reaction. Meskipun dengan adanya teknologi komunikasi baru yang bersifat interktif, namun faktor individu yang aktif menentukan mau interktif atau tidak. Karakteristik kedua dari sistem komunikasi yaitu de massified, kemampuan untuk meyampaikan pesan khusus antar individu dalam audience yang sangat banyak. Karakteristik ketiga dari sistem komunikasi yaitu asynchronous, kemampuan untuk mengirim dan menerima pesan pada waktu yang tepat pada individu (Noegroho, 2010: 12-13).

Laju komunikasi massa berbasis teknologi di dunia ini menyebabkan berbagai hal yang positif maupun hal yang bersifat negatif. Hal positif yang disebabkannya komunikasi teknologi media menyebabkan semua orang dapat melihat berbagai hal di luar wilayahnya dan menghilangkan sekat-sekat dunia tanpa harus datang langsung ke tempat-tempat, berbicara, dan bertatap muka langsung. Teknologi media memberikan kontribusi yang luar biasa bagi umat manusia, media menyebabkan jarak dan ruang tidak menjadi masalah lagi. Hal negatif dari komunikasi yaitu bisa menjauhkan yang dekat karena cara berkomunikasi yang bersifat tradisional atau komunikasi dengan cara bertatap muka langsung sudah mulai memudar, semua tergantikan dengan komunikasi bermedia. Apapun yang ada di dunia ini pasti ada baik dan buruknya, jika di dalam Agama Hindu hal baik dan buruk dalam kehidupan di sebut sebagai Rwabhineda.

Teknologi informasi didalam dunia pariwisata modern sangatlah penting karena teknologi informasi adalah suatu hal yang sangat fundamental dan besar perannya. Dalam industri pariwisata yang makin kompetitif dan terus berusaha untuk efektif dalam memberikan pelayanan dan informasi kepada calon konsumen tentang produk, waktu dan segala macam pelayanan yang mereka akan terima selama dalam perjalanan menuju kedaerah tujuan wisata maupun selama berda di daerah tujuan. Internet sebagai salah satu teknologi penyampaian informasi kepada dunia dan merupakan salah satu sarana komunikasi massa dapat mempermudah manusia menemukan segala informasi termasuk informasi pariwisata yang diinginkannya, sehingga membuat hidup jadi lebih mudah (Suwena dan Widyatmaja, 2017: 239-240 ).

Pariwisata Indonesia sebagai salah satu sektor penghasil devisa negara, haruslah dikembangkan dan ditingkatkan. Peran komunikasi dalam perkembangan pariwisata di dunia sangatlah penting. Bidang-bidang pariwisata seperti pada pemasaran daerah-daerah pariwisata maupun elemen - elemen pariwisata lainnya memerlukan peran komunikasi, baik komunikasi personal, komunikasi massa, komunikasi persuasif, maupun komunikasi lainnya (Bungin, 2015: 88). Sesungguhnya pariwisata telah dimulai sejak dimulainya peradaban 
manusia itu sendiri, ditandai oleh adanya pergerakan manusia yang melakukan ziarah atau perjalanan agama (Pitana dan Diarta, 2009: 32). Komunikasi massa dalam Pariwisata Indonesia di era globalisasi berperan penting karena dengan adanya media massa maka pengembangan sektor pariwisata di Indonesia terdapat banyak hotel, restoran maupun sarana transportasi sebagai penunjang berjalannya roda perekonomian di sektor pariwisata dan bisa diakses dengan mudah, hal ini dapat memberikan lapangan pekerjaan bagi penduduk disekitar lokasi wisata sehingga kemiskinan dapat dientaskan.

Indonesia dan seluruh negara ASEAN lainnya sudah mulai menjalani pasar bebas yang diberi label MEA yaitu Masyarakat Ekonomi ASEAN. Indonesia sudah mempersiapkan diri untuk benar-benar bisa dan mampu bersaing dengan negara lainnya dalam program Wonderful Indonesia yang dipromosikan lewat berbagai media termasuk media massa, sehingga masyarakat dari belahan dunia manapun bisa melihat keindahan serta kecantikan Indonesia. Melalui media massa maupun media online maka akan timbul keinginan mereka untuk benar-benar menikmati pariwisata serta budaya Indonesia dan sudah pasti pundi-pundi rupiah serta devisa pemerintah Indonesiapun bertambah. Mengembangkan serta memajukan pariwisata itu tidaklah semudah membalikkan telapak tangan, semua butuh proses yang lama dan dukungan semua pihak. Indonesia dalam hal ini sedang berusaha meningkatkan kualitasnya di semua sektor termasuk sektor pariwisata. Mencetak tenaga-tenaga ahli serta pemanfaatan sumber daya alam serta sumber daya alam yang masih belum terlalu terekspose di Dunia Internasional.

Bukti nyata bahwa pariwisata yang di sebar luaskan melalui komunikasi massa mampu memberikan penghargaan bergengsi untuk Indonesia di tingkat Dunia. Video promosi pariwisata Indonesia melalui situs, web, blog dan media sosial yang diwakili oleh Yogyakarta, Bali, Lombok, Jakarta, Toraja, Raja Ampat, serta Wakatobi mampu meraih kemenangan untuk kategori video terbaik versi pilihan publik atau masyarakat dunia melalui sistem vote. Pariwisata tanpa adanya dukungan dari komunikasi massa yang dalam hal ini adalah media massa tidak akan mampu menembus dan masuk kedalam masyarakat dunia. berdasarkan liputan dari travel.kompas.com pada tanggal 20 Desember 2017, Indonesia patut berbangga karena banyak penghargaan yang di dapat oleh Wonderful Indonesia, tentunya ini adalah penghargaan tingkat dunia. Berdasarkan data Kementerian Pariwisata menunjukkan, sejak kurun waktu 2016 Indonesia telah mendapat 46 penghargaan dari berbagai acara di 22 kota (Adikurnia, 2017: 1). Semakin terkenalnya pariwisata Indonesia di mata dunia tentu saja membuat kita sebagai rakyatnya berbangga dan ikut menjaga serta meningkatkan kepedulian 
kita terhadap destinasi - destinasi wisata yang ada di sekitar kita agar wisatawana asing ingin datang ke Indonesia dan bisa kembali lagi membawa serta sanak keluarganya.

\section{Pariwisata dan Wisatawan}

Pariwisata Indonesia sebagai salah satu sektor penting di Negara ini yang mengasilkan devisa selain sektor minyak bumi dan gas. Menurut Yoeti (dalam Suwena dan Widyatmaja, 2017 : 19) menyatakan secara etimologi, kata pariwisata berasal dari bahasa sansekerta yang terdiri dari dua kata yaitu pari dan wisata. Pari artinya banyak atau berkeliling, dan wisata artinya pergi atau bepergian. Jadi pariwisata berarti perjalanan yang dilakukan berkali-kali atau berputar-putar, dari suatu tempat ke tempat lain. Pemerintah Indonesia memberikan definisi berkait dengan pariwisata dituangkan dalam UU No.10/2009, yang dimaksud dengan pariwisata adalah berbagai macam kegiatan wisata dan didukung oleh berbagai fasilitas serta layanan yang disediakan masyarakat, pengusaha, pemerintah, dan pemerintah daerah (Suwena \& Widyatmaja, 2017 : 22 ). Menurut Pitana dan Diarta (2009 : 32-33) sebagai berikut.

Sesungguhnya pariwisata telah dimulai sejak dimulainya peradaban manusia itu sendiri, ditandai oleh adanya pergerakan manusia yang melakukan ziarah atau perjalanan agama. Tonggak-tonggak sejarah dalam pariwisata sebagai fenomena modern dapat ditelusuri dari perjalanan Marcopolo (1254-1324) yang menjelajahi Eropa samapai ke Tiongkok, untuk kemudian kembali ke Venesia. Kemudian dilanjutkan dengan perjalan Pangeran Henry (1394-1460), Christopher Columbus (1451-1506), dan Vasco da Gama (akhir abad XV). Pada zaman Prasejarah, manusia hidup berpindah-pindah sehingga perjalanan yang jauh (traveling) merupakan gaya dan cara untuk bertahan hidup. Mereka serinng melintasi tempat yang jauh untuk mencari makanan, minuman, pakaian, dan iklim yang mendukung kehidupannya. Di abad 11 sampai abad 15 dalam sejarah peradaban barat, terjadi model baru perjalanan manusia untuk melakukan ziarah ke tempat khusus untuk alasan religius. Pada abad 17 sampai abad 20 merupakan era perpindahan dan perjalanan manusia melintasi Negara dan benua. Beberapa orang yang telah mencapai tingkat kesejahteraan dan mempunyai waktu luang mulai melakukan perjalanan bukan untuk mencari tempat bermukim baru, tetapi untuk kesenangan dan mengisi waktu luang atau untuk alasan budaya. Fenomena terakhir inilah yang menjadi potret awal lahirnya pariwisata, yang mulai meledak di akhir abad ke-20.

Kegiatan berwisata dapat bermacam jenisnya seperti, wisata kuliner yaitu wisata yang dilakukan karena makanan merupakan salah satu kebutuhan pokok manusia, para penikmat makanan dapat menikmati makanan khas dari daerah yang dikunjunginya serta dapat membeli oleh-oleh untuk para kerabatnya yang berupa makanan-makanan ringan ciri khas daerah setempat yang sudah di packing rapi. Wisata Sejarah, berupa perjalanan yang 
dilakukan untuk mengunjungi tempat-tempat bersejarah maupun museum sebagai tempat menyimpan benda-benda bersejarah. Wisata bahari, merupakan perjalanan yang dilakukan pada saat waktu luang menuju pantai daan menikmati segala kegiatan yang bisa dilakukan disana, dapat berupa menyelam ke dasar laut, berselancar dengan ombak-ombak yang tingi, bermain banana boat, jetski dan lain sebagainya. Dari berbagai jenis kegiatan berwisata, salah satunya adalah wisata religi dilakukan ketika seseorang memiliki waktu yang senggang atau watu luang, sehingga kegiatan berwisata tidak terganggu dan mereka bisa menikmati perjalanan wisata religi mereka. Di saat jaman modern ini beragam produk- produk pariwisata religi juga ditawarkan melalui media massa. Tathagati (2015: 67) dalam bukunya yang berjudul Super Tourism Preneur menyatakan, para pelaku bisnis pariwisata memanfaatkan media massa utuk menawarkan produk-produknya misalnya, memasang iklan baris di surat kabar, promosi melalui radio, dimana produk yang ditawarkan dapat disebutkan oleh penyiar dalam siaran regular mereka.

Pengertian dari produk pariwisata menurut Burkat dan Medlik ( dalam Andayani, 2013: 2) yaitu susunan produk yang terpadu, yanag terdiri dari objek dan daya tarik wisata, transportasi, akomodasi, dan hiburan, dimana tiap unsur produk pariwisata dipersiapkan oleh masing-masing perusahaan dan ditawarkan secara terpisah kepada konsumen, yaitu wisatawan. Mason dan Poerwanto (dalam Andayani, 2013: 3), membuat rumusan tentang komponen-komponen produk wisata yaitu : atraksi adalah daya tarik wisata baik alam, budaya maupun buatan manusia seperti festival atau pentas seni, aksebilitas adalah kemudahan dalam memperoleh atau mencapai tujuan wisata seperti organisasi kepariwisataan (travel agent), amenities adalah fasilitas untuk memperoleh kesenangan yang dalam hal ini dapat berbentuk akomodasi, kebersihan dan keramah-tamahan, networking adalah jaringan kerjasama yang berkaitan dengan produk yang ditawarkan baik lokal, nasional, maupun internasional. Dalam Wisata Religi, khususnya wisata religi Hindu maka produk-produk yang dapat ditawarkan antara lain produk perjalanan menuju Pura Besakih, Pura Uluwatu, Pura Batur di Bali bagi umat Hindu yang berada di luar Pulau Bali. Produk wisata religi keluar negri yang dapat di tawarkan berupa perjalanan ke India, mengunjungi sungai gangga dan tempat-tempat yang lainnya.

Dalam industri pariwisata hal penting lainnya yang harus diperhatikan yaitu wisatawan. Kata wisatawan berasal dari bahasa Sanskerta "wisata” yang berarti perjalanan yang sama atau dapat disamakan dengan kata "travel" dalam bahasa Inggris, maka wisatawan sama artinya dengan kata traveller. Namun dalam pengertian yang umum diterima 
oleh masyarakat Indonesia sesungguhnya bukanlah demikian, kata wisatawan selalu diasosiasikan dengan kata tourist (bahasa Inggris). kata tourist itu sendiri, berasal dari kata tour yang berarti perjalanan yang dilakukan dari suatu tempat ke tempat lain dan orang yang melakukan perjalanan (tour) ini dalam bahasa Inggris disebut dengan istilah "tourist" ( Suwena \& Widyatmaja, 2017 : 41). Secara umum wisatawan merupakan bagian dari traveller atau visitor. Kata wisatawan merujuk kepada orang (people), untuk dapat disebut sebagai wisatawan seseorang haruslah seorang traveller atau seorang visitor. Seorang visitor adalah seorang traveller, tetapi tidak semua traveller adalah tourist. Traveller memiliki konsep yang lebih luas, yang dapat mengacu kepada orang yang mempunyai beragam peran dalam masyarakat yang melakukan kegiatan rutin ke tempat kerja, sekolah dan sebagainya, sebagai aktivitas sehari-hari. Orang-orang menurut kategori ini sama sekali tidak dapat dikatakan sebagai tourist (Pitana dan Diarta, 2009 : 35). Kata wisatawan merujuk kepada orang, pengertian umum mengenai wisatawan biasanya dipakai dalam pemikiran dan komunikasi sehari-hari ketika seseorang mendeskripsikan berbagai perilaku atau perwujudan, baik orang maupun tempat yang touristy yaitu tempat yang banyak dikunjungi orang sehingga dianggap daerah wisata atau touristic yaitu sifat yang mencerminkan seseorang berprilaku seperti seorang wisatawan (Pitana dan Diarta, 2009 : 36).

Berdasarkan Bab I Pasal 1 Undang-Undang Republik Indonesia Nomor 10 Tahun 2009 tentang kepariwisataan (dalam Suwena \& Widyatmaja, 2017: 22-23) menjelaskan sebagai berikut.

Wisata adalah kegiatan perjalanan yang dilakukan oleh sebagian atau sekelompok orang dengan mengunjungi tempat tertentu untuk tujuan rekreasi dan pengembangan diri. Wisatawan adalah orang yang melakukan wisata. Pariwisata adalah berbagai macam kegiatan wisata dan di dukung berbagai fasilitas serta layanan yang disediakan oleh masyarakat, pengusaha, pemerintah, dan pemerintah daerah. Kepariwisataan adalah keseluruhan kegiatan yang terkait dengan pariwisata daan bersifat multidimensi serta multidisplin yang muncul sebagai wujud kebutuhan setiap orang dan Negara serta interaksi antara wisatawan dan masyarakat setempat, sesame wisatawan, pemerintah, pemerintah daerah, dan pengusaha.

Pemerintah Indonesia melalui instruksi Prsiden No. 9 Tahun 1969 (dalam Suwena \&

Widyatmaja, 2017 : 44 ) memberikan definisi wisatawan sebagai berikut.

Wisatawan (tourist) adalah setiap orang yang bepergian dari tempat tinggalnya untuk berkunjung ke tempat lain dengan menikmati perjalanannya dan kunjungannya itu. Berdasarkan batasan-batasan tersebut, maka kita dapat memberi ciri tentang seseorang itu dapat disebut sebagai wisatawan: perjalanan itu dilakukan lebih dari 24 jam, perjalanan itu dilakukannya untuk sementara waktu, orang yang melakukannya tidak mencari nafkah di tempat atau Negara yang di kunjunginya. 
Perkembangan teknologi informasi dimana keberadaan internet membuat persebaran informasi hal yang terkait wisata menjadi nyaris tak terbatas. Lewat internet, wisatawan dapat mencari informasi soal destinasi wisata dengan sangat mudah melalui cerita pengalaman wisatawan lain mengenai destinasi wisata tertentu. Pelaku bisnis pariwisata memanfaatkan perkembangan teknologi informasi sebagai ajang promosi (Tathagati, 2015: 4). Dari promosipromosi yang dilakukan pelaku bisinis pariwisata, seorang wisatawan bisa tertarik untuk melakukan sebuah perjalanan religi yang di dalam Agama Hindu disebut sebagai Tirtayatra.

\section{Tirthayatra sebagai Pariwisata Religi Hindu}

Umat beragama Hindu di era globalisasi dengan beragam informasi yang bisa kita dapatkan melalui media massa serta media online, sudah sepatutnyalah kita juga berusaha mencari informasi-informasi untuk mempertebal rasa percaya serta keyakinan kita kepada Ida Sang Hyang Widhi Wasa. Dalam Agama Hindu, di ajarkan tentang keyakinan yang harus dimiliki umatnya yang di sebut sebagai Panca Sradha dimana diartikan sebagai lima keyakinan, yaitu percaya akan adanya Ida Sang Hyang Widhi Wasa (Tuhan), percaya akan adanya atman (roh), percaya akan adanya karma (hasil perbuatan), percaya akan adanya punarbhawa/ samsara (kelahiran kembali), percaya akan adanya moksa (penyatuan dengan Ida Sang Hyang Widhi Wasa). Manusia adalah mahluk yang paling utama yang di ciptakan oleh Tuhan ke dunia ini, karena manusia diberikan pikiran agar dapat memikirkan dahulu perbuatan baik dan buruk yang akan mereka lakukan. Hali ini tersurat dalam Sarasamuscaya 4, yang berbunyi "Apan ikang dadi wwang, uttama juga ya, nimittaning mangkana, wenang ya tumulung awakya sangkeng sangsara, mangkasadhanang subhakarma, hingganing kottamaning dadi wwang ika "yang artinya: menjelma menjadi manusia itu adalah sungguh sungguh utama, karena ia dapat menolong dirinya dari keadaan sengsara (lahir dan mati berulang - ulang) dengan jalan berbuat baik, demikianlah keuntungannya menjelma menjadi manusia (Kadjeng, 2010:4)

Berbagai jalan dapat ditempuh untuk mendekatkan diri dengan Tuhan, hal ini tersurat dalam Bhagawadgita, IV sloka 11 yang berbunyi "sejauh mana semua orang menyerahkan diri kepada-Ku, Aku menganugerahi mereka sesuai dengan penyerahan dirinya itu. Semua menempuh jalan- Ku dalam segala hal, wahai putera Prtha. Salah satu jalan untuk mendekatkan diri dengan Ida Sang Hyang Widhi Wasa adalah Tirtha Yatra” (Maswinara, 2008: 226). Menurut (Suparta, 2005 : 8) tirtayatra berarti sebagai berikut.

Tirtayatra berasal dari bahasa Sansekerta, yang terdiri dari dua kata yakni Tirtha dan Yatra. Tirtha menurut kamus bahasa sansekerta dan menurut para ahli mempunyai 
banyak pengertian seperti pemandian, sungai, kesucian air, toya atau air suci, sungai yang suci atau tempat berziarah. Dari berbagai pengertian tampaknya tirta mempunyai makna kearah yang sama yakni membersihkan atau menyucikan. Sedangkan secara kenyataannya dari pengertian di atas mengarah ke wujud air. Dengan demikian secara umum dapat kita simpulkan tirta adalah air. Sedangkan yatra berarti perjalanan suci. Jadi tirtayatra adalah perjalanan suci untuk mendapatkan atau memperoleh air suci

Pada Sarasamucaya 279 (dalam Kadjeng, 2010: 221), menyatakan sebab keutamaan tirthayatra itu, amat suci, lebih utama daripada pensucian dengan yadnya, tirthayatra (kunjungan ke tempat - tempat suci) dapat dilakukan oleh orang miskin. Seseorang apapun status dirinya di masyarakat dan dia miskin sekalipun tetap dapat melakukan tirthayatra karena semua itu dilakukan berdasarka ketulusannya dalam melakukan perjalanan suci untk mendapatkan tirtha amerta atau air kehidupan.

Penyucian jiwa dan raga yang dilakukan umat Hindu yang melakukan tirthayatra sebagai salah satu jalan bhakti kepada Ida Sang Hyang Widhi Wasa dapat diakui bahwa ia orang yang memiliki jiwa suci. Hal ini tersurat dalam Bhagawad Gita IX.30 yang berbunyi meskipun seseorang melakukan perbuatan paling jijik, kalau ia tekun dalam bhakti, ia harus diakui sebagai orang suci karena ia mantab dalam ketabahan hatinya dengan cara yang benar (Prabhupada, 2000: 492).

Jika dahulu, para leluhur kita seperti Maharesi Agastya, Resi Markandeya serta Dang Hyang Nirartha melakukan trithayatra hanya dengan kebulatan tekad dan dengan kemampuannya sendiri, berjalan kaki serta mendaki gunung, terombang ambing ditengah lautan dan melintasi pulau hanya untuk mendapatkan air suci. Dewasa ini tirthayatra dilakukan oleh umat Hindu tidak hanya didalam negeri tetapi juga hingga luar negeri, dikarenakan mudahnya alat-alat transportasi serta berkembangnya produk dan jasa didalam melakukan tirthayatra atau pariwisata religi Hindu. Produk dan jasa itu ditawarkan oleh agen-agen perjalanan dalam paket wisata ke suatu tempat, seperti ke Malaysia, India, Thailand dan lainya.

Pariwisata religi atau religion tourism, yaitu jenis pariwisata dimana motivasi wisatawan untuk melakukan perjalanan tujuannya melihat atau menyaksikan upacaraupacara keagamaan, seperti upacara Bali Krama di Besakih, haji dan umroh bagi agama Islam, dan lainnya (Suwena \& Widyatmaja, 2017: 22). Koentjaraningrat (1977: 28), menyatakan ada empat unsur pokok dari religi pada umumnya, yaitu emosi keagamaan atau getaran jiwa yang menyebabkan manusia menjalankan kelakuan keagamaan, sistem kepercayaan atau bayangan-bayangan manusia tentang bentuk dunia, alam, alam gaib, hidup, maut dan sebagainya, sistem upacara keagamaan yang bertujuan mencari hubungan dengan 
dunia gaib berdasarkan atas sistem kepercayaan tersebut, kelompok keagamaan atau kesatuan-kesatuan sosial yang mengonsepsikan dan mengaktifkan religi beserta sistem upacara-upacara keagamannya.

Emosi keagamaan atau getaran jiwa yang menyebabkan manusia melakukan perjalanan wisata religi atau tirthayatra. Tirthayatra sebagai pariwisata religi yang didalam pelaksanaan kegiatan tirthayatra di jaman yang serba modern ini dengan segala kemudahan mengakses informasi melalui internet tempat-tempat yang bisa dikunjungi, transprortasi apa saja yang bisa menuju tempat wisata, lama waktu tempuh perjalanana tergantung lokasi tempat. Fenomena booming wisatawan ini menciptakan beragam tawaran produk wisata termasuk wisata religi. Semakin menjamurnya agen-agen perjalanan wisata yang menyediakan paket untuk melakukan tirthayatra baik di dalam negeri maupun luar negeri serta ada juga maskapai penerbangan yang menyediakan paket tirthayatra bekerja sama dengan agen-agen perjalanan wisata lokal.

Beberapa agen perjalanan menawarkan produk perjalanan melalui berbagai media seperti website perusahaan, iklan, selebaran dengan bermacam variasi harga dan tempat tujuan tirthayatra. Antara lain rute perjalanan tirthayatra Blambangan - Gunung Raung Lumajang - Bromo. Adapula paket tirthayatra keluar negeri seperti mengunjungi India, Malaysia, Thailand, Nepal dan Sri Langka. Paket wisata tirthayatra dalam negeri biasanya mengunjungi peninggalan bersejarah Hindu-Budha seperti Candi Borobudur, Candi Prambanan, Candi Cetho, Pura Semeru, Blambangan, Alas Purwo, Gunung Bromo, Giri Selaka, Mergo Wening, Gunung Salak, Pura Batur, Pura Besakih, Pura Pulaki, Pura Uluwatu, Pura Goa Lawah, Pura Lempuyang, serta situs Hindu lainnya. Paket wisata religi ke India mengunjungi pegunungan Himalaya, Sungai Yamuna, Sungai Gangga, Candi Hindu, dan objek religi lainnya.

\section{Simpulan}

Di era milenial saat ini sarana prasarana komunikasi semakin berkembang pesat. Komunkasi sudah mengglobal sehingga orang dibelahan bumi yang lain dengan mudah memperoleh informasi. Perkembangan pesat tersebut juga merambah dunia pariwisata. Pelaku pariwisata berlomba-lomba menawarkan produknya untuk memikat wisatawan. Keinginan manusia untuk memenuhi emosi keagaamaan atau getaran jiwa yang menyebabkan manusia menjalankan kelakuan keagamaan dengan cara melakukan perjalan spiritual ke tempat suci agamanya. Umat Hindu melakukan penyucian jiwa dan raga dengan menjalankan tirthayatra. Hal tersebut merupakan pangsa pasar yang dibidik oleh pelaku 
industri pariwisata dengan menawarkan produk wisata religi atau tirthayatra. Perjalanan tirthayatra umat Hindu merupakan media komunikasi dengan Ida Sang Hyang Widhi Wasa sebagai aktuliasasi emosi keagamaan dan salah satu jalan bhakti kepada Ida Sang Hyang Widhi Wasa sehingga jiwa suci kembali.

\section{Daftar Pustaka}

Adikurnia, Muhammad Irzal. (2017). "Penghargaaan Bergengsi untuk Pariwisata Indonesia" https://travel.kompas.com/. Diakses tanggal 4 Maret 2018.

Arifin, Anwar. (2010). Ilmu Komunikasi Sebuah Pengantar Ringkas, Jakarta: PT. Raja Grafindo Persada.

Bungin, Burhan. (2015). Komunikasi Pariwisata Pemasaran dan Brand Destinasi. Jakarta: Kencana.

Effendy, Onong Uchjana. (2011). Komunikasi Teori dan Praktek. Bandung: Remaja Rosdakarya.

Kadjeng, I Nyoman. (2010). Sarasamuccaya. Surabaya: Paramita.

Koentjaraningrat. (1977). Beberapa Pokok Antropologi Sosial. Jakarta: PT. Dian Rakyat.

Maswinara, I Wayan. (2008). Bhagawad Gita. Surabaya: Paramita.

Morrisan. (2013). Teori Komunikasi Individu Hingga Massa. Jakarta: Kencana Prenada Media Group.

Ngalimun. (2017). Ilmu Komunikasi Sebuah Pengantar Praktis. Yogyakarta: Pustaka Baru Press.

Noegroho, Agoeng . (2010). Teknologi Komunikasi, Yogyakarta: Graha Ilmu.

Pitana, I Gde dan Diarta, I Ketut Surya. 2009. Pengantar Ilmu Komunikasi. Yogyakarta: Andi Offset.

Prabupada, Sri Srimad A.C. Bhaktivedanta Swami Prabhupada. (2000). Bhagawad Gita Menurut Aslinya. Jakarta: Hanuman Sakti.

Rohim, Syaiful. (2009). Teori Komunikasi: Perspektif, Ragam dan Aplikasi. Jakarta: Rineka Cipta.

Ruben, Brent D dan Stewart Lea P. (2017). Komunikasi dan Perilaku Manusia. Jakarta: PT. Raja Grafindo Persada.

Suparta, INK. (2005). Keutamaan Tirthayatra. Denpasar. CV. Kayumas Agung

Suwena, I Ketut dan I Gusti Ngurah Widyatmaja. (2017). Pengetahuan Dasar Ilmu Pariwisata. Denpasar: Pustaka Larasan.

Tathagati, Arini. (2015). Super Tourism Preneur. Yogyakarta: Andi Offset.

Vivian, Jhon. ( 2008). Teori Komunikasi Massa. Jakarta: Kencana Prenada Media Group. 